\title{
KEWENANGAN PENGADILAN NEGERI MENGELUARKAN SALINAN AKTA DARI PROTOKOL NOTARIS
}

\author{
Ratna Dewi Nirwana Sari \\ DPRD Kabupaten Blitar \\ J1. Kotabaru No. 10 Kanigoro, Blitar \\ Email: dewimadame9@gmail.com
}

\begin{abstract}
Abstrak
Ada kewenangan Pengadilan Negeri untuk mengeluarkan salinan akta dari protokol notaris yang minuta aktanya telah berumur 25 tahun dan perlindungan hukum terhadap notaris serta para pihak/ahli waris terkait minuta akta yang masih disimpan di Pengadilan Negeri. Sejak berlakunya Undang-Undang Jabatan Notaris (UUJN), Pengadilan Negeri tidak mempunyai wewenang untuk mengeluarkan salinan akta dari protokol notaris yang minuta aktanya sudah berumur 25 tahun. Adapun bentuk perlindungan hukum bagi notaris sudah diatur dalam UUJN yang antara lain: memiliki hak ingkar dan cara pemanggilan notaris oleh penegak hukum terkait akta yang dibuatnya. Sedangkan perkindungan hukum bagi para pihak/ahli warisnya belum tercapai karena tidak adanya kepastian hukum terkait pihak yang berwenang mengeluarkan Salinan akta dari minuta kata yang berumur 25 tahun dan masih disimpan di Pengadilan Negeri.
\end{abstract}

Kata Kunci: kewenangan, akta, pengadilan, notaris, perlindungan

\section{Abstract}

There is the authority of the District Court to issue a copy of the deed from the notary protocol whose actuality is 25 years old and legal protection of the notary and parties / heirs related to the document deed that is still kept in the District Court. Since the entry into force of the Notary Position Act (UUJN), the District Court has no authority to issue a copy of the deed from the notary protocol whose the deed of a 25 years old. The form of legal protection for notaries has been regulated in UUJN, which among others: has the right to deny and how to summon a notary by law enforcers related to the deed he made. While legal protection for the parties I heirs has not been reached because there is no legal certainty related to the party authorized to issue a copy of the deed of a 25-year-old and still kept in the District Court.

Keywords: authority, deed, court, notary, protection 


\section{PENDAHULUAN}

Sejarah lahirnya jabatan notaris disebabkan kebutuhan masyarakat yang semakin berkembang. Jabatan notaris telah ada di Indonesia sejak abad ke-17 yakni pada tanggal 27 Agustus 1620. Perkembangan masyarakat mengalami peningkatan dari masa ke masamembuat masyarakat semakin kritis, sehingga menuntut pemerintah agar menghadirkan solusi untuk membantu dan memberikan pelayanan kepada masyarakat yang semakin sadar akanpentingnya pembuktian dari dampak hukum yang mungkin akan terjadi. Salah satunya dengan alat bukti tertulis yang bersifat autentik terkait suatu peristiwa atau perbuatan hukum.Oleh karena itu, aturan hukum menghendaki dihadirkannya jabatan notaris dan seorang pejabat notaris diharapkan tidak memihak atau memiliki posisi netral.

Jabatan notaris di Indonesia berpedoman pada UndangUndang Nomor 30 Tahun 2004 tentang Jabatan Notaris yang kini diperbaharui dengan Undang-Undang Nomor 2 Tahun 2014 tentang Jabatan Notaris yang dikenal dengan UUJNP. Jabatan notaris memiliki posisi yang istimewa di mana dianggap sebagai pejabat umum yang memiliki wewenang untuk membuat suatu akta autentik dan wewenang lainnya sesuai dengan Pasal 1 angka 1 UUJNP.

Seorang notaris juga memiliki kewajiban-kewajiban bersamaan dengan kewenangan yang dapat dilakukan dalam mengemban jabatannya.Salah satunya terkait pada bidang administrasi, yakni menyimpan dan memelihara seluruh dokumen termasuk diantaranya akta yang dikumpulkan sesuai dengan nomor minuta akta beserta-dokumen lainnya yang disebut dengan protokol notaris. Pasal 1 ayat 13 UndangUndang Nomor 2 Tahun 2014 Tentang UUJN menyebutkan bahwa protokol notaris terdiri darikumpulan dokumen yang termasuk dalam kategori arsip negara sehingga penyimpanan dan pemeliharaan wajib dilakukan oleh notaris sebagaimana layaknya perlakuan khusus terhadap dokumen negara sehingga tetap terjaga rahasia dan keautentikannya.

Adapun dokumen-dokumen yang termasuk dalam protokol notaris dijelaskan di dalam penjelasan Pasal 62 UndangUndang Nomor 2 Tahun 2014 tentang Peraturan Jabatan Notaris, yakni: minuta akta, buku daftar akta atau repertorium, buku daftar akta di bawah tangan yang penandatanganannya dilakukan dihadapan notaris atau akta di bawah tangan yang didaftarkan, buku daftar nama penghadap atau klapper, buku daftar protes, buku daftar wasiat, dan buku daftar lain yang menjadi tanggung jawab notaris untuk disimpan sesuai dengan regulasi UndangUndang. Dalam hal notaris yang bertanggungjawab tidak dapat melanjutkan tugas menyimpan protokol notaris, maka dapat dilakukan peralihan protokol 
notaris kepada notaris pengganti yang ditunjuk atau kepada pejabat notaris sementara.

Sebab-sebab dilakukannya peralihan protokol notaris kepada notaris yang ditunjuk untuk memegang protokol notaris lain disebutkan dalam Pasal 62 UUJN, yakni: telah meninggal dunia, telah pension, mengalihkan atas keinginan sendiri, tidak memiliki kemampuan secara rohani dan/atau jasmani untuk menjalankan tugasnya sebagai notaris secara terus menerus lebih dari 3 tahun, telah menjadi pejabat negara,

telah pindah wilayah jabatan, diberhentikan sementara, atau diberhentikan dengan tidak hormat.

Menjalankan suatu jabatan tak terkecuali bagi seorang pejabat notaris tentu memiliki batasan-batasan yang tidak dapat diprediksi, termasuk kemampuan yang dipengaruhi usia biologis sesuai aturan yang ada di dalam UUJN, yakni hingga berusia 65 tahun. Adanya batasan usia tersebut tentunya berdampak terhadap tanggung jawab penyimpanan dan pemeliharaan protokol notaris. Faktor lain yang mungkin terjadi seperti mengalami kerusakan dikarenakan umur kertas yang disimpan dalam waktu lama, termakan oleh hewan seperti rayap atau tikus bahkan mungkin kehilangan Protokol disebabkan bencana alam yang menimpa wilayah kerja dan kediaman kantor notaris terkait. Terlepas dari semua faktor yang mungkin terjadi, notaris tetap dapat dituntut untuk bertanggungjawab penuh terkait semua akta yang telah dibuatnya mulai dari awal diangkat sebagai Notaris, telah pensiun atau hingga habis masa kerja, bahkan ketika Notaris telah meninggal dunia sesuai ketentuan dalam Pasal 8 ayat 1 huruf $a$ dan $b$ UUJNP.

Berdasarkan hal tersebut, Pasal 35 UUJNP memberikan solusi dan menyatakan bahwa, keluarga dari pihak notaris yang meninggal dunia wajib memberi informasi kepada Majelis Pengawas Daerah (MPD) notaris selambat-lambatnya 7 (tujuh) hari kerja. Kemudian jika notaris yang bersangkutan meninggal dunia saatmasih menjalankan cuti kerja, maka tugas jabatannya dialihkan kepada notaris pengganti yang ditunjuk untuk menjadi pejabat sementara notaris dengan waktu paling lama 30 hari dihitung sejak tanggal notaris meninggal dunia. Kemudian pejabat sementara notaris tersebut mengalihkan protokol notaris kepada MPD dari notaris yang telah meninggal dunia selambat-lambatnya 60 (enam puluh) hari sejak tanggal notaris meninggal dunia.

Berkaitan dengan kewenangan penyerahan protokol notaris, ketentuannya terdapat pada Pasal 63 UUJNP, bahwa peralihan protokol seperti yang tercantum dalam pasal 62 dialihkan dalam waktu 30 hari. Setelah itu dibuatkan berita acara peralihan Protokol Notaris yang mana 
wajib mengikutsertakan tandatangan penyerah dan penerima protokol notaris, protokol notaris yang dialihkan dari notaris yang menyerahkan kepada penerima protokol dan pada waktu peralihannya protokol tersebut telah berumur 25 tahun atau lebih dialihkan oleh notaris penerima protokol kepada MPD.

Hal tersebut berbeda dengan saat sebelum berlakunya UUJN, yang mana protokol notaris yang sudah berumur 25 tahun atau lebih dilimpahkan ke Pengadilan Negeri. Sehingga menjadi timbul pertanyaan apakah Pengadilan Negeri berwenang mengeluarkan Salinan tersebut karena terkait protokol notaris diserahkan kepada MPD berlaku setelah dikeluarkannya UUJN dan bagaimana perlindungan hukumnya terhadap pejabat notaris dan para pihak/ahli warisnya terkait protokol notaris yang masih disimpan di Pengadilan Negeri?

\section{METODE PENELITIAN}

Jenis penelitian yang digunakan adalah jenis penelitian yuridisnormatif. Untuk mengkaji pokok permasalahan, metode yang digunakan pada penelitian ini adalah metode penelitian hukum normatif, untuk itu halhal yang menjadi fokus dan sentral penelitian ini adalah berbagai aturan hukum dan literatur atau bahan yang berkaitan dengan hukum. Pendekatan yang digunakan dalam penelitian ini adalah dengan mengkaji peraturan perundang-undangan (statue approach) untuk menelaah dan memahami aturan yang terkait dengan isu hukum yang sedang penulis teliti. Penelitian yuridis-normatif ini juga menggunakan pendekatan konseptual (conseptual approach).

Adapun bahan hukum yang digunakan adalah bahan hukum primer sebagai sumber utama penelitian, bahan hukum sekunder sebagai sumber kedua yang bisa penulis dapat dari melakukan wawancara dengan responden terakit dan bahan hukum tersier sebagai sumber ketiga yang bisa penulis dapat dari jurnal-jurnal dan kamus-kamus hukum terkait. ${ }^{1}$ Teknik pengumpulan bahan hukum yang digunakan adalah studi kepustakaan dengan analisis yang menggunakan metode penelitian deskriptif analitis.

\section{PEMBAHASAN}

\section{Kewenangan Pengadilan untuk Mengeluarkan Salinan Akta}

Notaris dalam mengemban jabatannya sebagai pejabat umum memiliki kewenangan dalam membuat akta autentik. Akta autentik sendiri merupakan akta yang dibuat dan dapat dijadikan sebagai alat bukti sempurna dihadapan pengadilan selama telah dibuat sesuai dengan syarat

${ }^{1}$ Habib Adjie, Sanksi Perdata dan Administratif Terhadap Notaris

Sebagai Pejabat Publik, (Bandung; Refika Aditama, 2008), hal. 29. 
dan ketentuannya dan tidak ada kemungkinan dari pihak lawan dapat membuktikan sebaliknya. Namun jika ada syarat yang belum terpenuhi meskipun masih dapat dibuktikan, maka oleh pengadilan dinyatakan dapat digunakan sebagai bukti dengan status akta di bawah tangan.Jika sudah berstatus seperti itu, maka nilai pembuktiannya diserahkan kepada Hakim oleh para pihak yang membuat akta tersebut. ${ }^{2}$ Karena kekuatan pembuktian akta di bawah tangan tidak sekuat akta autentik. Atas hal ini, para pihak dan juga notaris diharapkan lebih berhati-hati dalam proses pembuatan suatu akta perbuatan hukum. ${ }^{3}$

Hal ini membuat seorang notaris harus siap dan sanggup dibebani pertanggungjawaban hukum atas tugasnya yang berkaitan dengan membuat akta tersebut. Kategori pertanggungjawaban notaris termasuk pada kebenaran materiil, ${ }^{4}$ sehingga dalam menjalankan tugasnya notaris juga sering mendapat masalah yang berhubungan tentang pembuatan akta. Kumpulan akta yang dibuat oleh notaris kemudian disebut dengan protokol notaris dapat dijadikan sebagai bukti autentik dihadapan Pengadilan untuk mencapai kepastian, ketertiban dan perlindungan hukum bagi pihak-pihak yang berkepentingan secara khusus dan masyarakat secara umum.

Berawal dari para pihak datang menghadap di kantor notaris, notaris mendengarkan keinginan mereka akan suatu perbuatan hukum, notaris memberikan nasihat hukum yang sesuai dan tidak memihak, kemudian menuangkannya pada format akta tertentu serta ditandatangani di atas materai oleh (pihak pertama) para pihak, para saksi dan notaris yang bersangkutan. Jika semua proses tersebut dilakukan dan akta yang dibuat telah sesuai dengan peraturan jabatan notaris maka akta tersebut telah menjadi sebuah akta autentik.

Protokol notaris juga dianggap sebagai arsip negara serta merupakan bagian administrasi dari kantor notaris yang sangat penting karena fungsi dan perannya, sehingga notaris dapat menjalankan jabatannya dengan baik dan benar. Selama melaksanakan tugas jabatannya, notaris harus menjunjung tinggi UUJN, peraturan perundang-undangan lain dan etika profesi notaris. Adapun salah satu kewajiban notaris diatur dalam Pasal 16 ayat (1) huruf a bahwa seorang notaris harus "bertindak jujur, seksama, mandiri, tidak berpihak dan menjaga kepentingan pihak terkait dalam perbuatan hukum".

${ }^{2}$ Herlien Budiono, Akte Notaris Melalui Media Elektronik, (Bandung: UpgradingRefreshing Course Ikatan Notaris Indonesia, 2003), hal. 5-6

${ }^{3}$ Herlien Budiono, Kumpulan Tulisan Hukum Perdata Di Bidang Kenotariatan. (Jakarta: Citra Aditya Bakti, 2015), hal. 54.

${ }^{4}$ Abdul Ghofur Anshori, Lembaga Kenotariatan Indonesia, Perspektif Hukum dan Etika, (Yogyakarta: UII Press, 2009), hal. 41 
Seorang ahli bernama Tan Thong Kie memberikan pendapat bahwa protokol merupakan milik masyarakat, bukan milik seorang notaris yang membuat akta-akta, bukan juga milik notaris yang diberi tugas/ditunjuk oleh Menteri Kehakiman atas penyimpanannya. ${ }^{5}$ Karena pada hakikatnya isi dokumen dalam protokol notaris merupakan penjabaran keinginan dan kepentingan dari para pihak yang identitasnya ada di dalam dokumen. Dapat dikatakan bahwa seorang notaris merupakan sarana dari para pihak yang berkepentingan untuk menjalin suatu perbuatan dan hubungan hukum karena mengerti dan paham dibidang tersebut.

Minuta akta notaris yang merupakan akta autentik memiliki ketetentuan tidak diperkenankan keluar dari kantor notaris, maka para pihak yang berkepentingan harus datang menghadap ke kantor notaris, pun demikian jika akta perjanjian telah dibuat maka pengesahannya harus tetap dilakukan dihadapan dan di kantor notaris setelah itu akan dikumpulkan dan dibukukan oleh notaris dan dijahit jadi satu. Nantinya para pihak hanya diberi Salinan akta yang telah diberi stempel dan ditandatangani di atas materai oleh notaris yang bersangkutan setelah notaris melaporkan ke Kementerian Kehakiman. Atas kepentingan tersebut maka pembuatan minuta akta dan pemberian Salinan akta tersebut harus dijaga dan diawasi.

Tindakan memeriksa, penjagaan dan pengawasan terhadap protokol serta pemberian sanksi terhadap notaris pada saat Undang-Undang Nomor 30 Tahun 2004 Jo Undang-Undang Nomor 2 Tahun 2014 Tentang Peraturan Jabatan Notaris belum berlaku,menjadi wewenang dari Badan Peradilan yang ada pada waktu itu .

Kemudian tugas mengawasi terhadap notaris menjadi wewenang Peradilan Umum dan Mahkamah Agung sesuai dengan Pasal 32 dan Pasal 54 Undang-Undang Nomor 13 Tahun 1965 Tentang Pengadilan Dalam Lingkungan Peradilan Umum dan Mahkamah Agung. ${ }^{6}$ Dengan demikian perlu adanya suatu pembaharuan hukum terhadap kepentingan pengawasan dan pembinaan yang berkelanjutan bagi para pejabat notaris saat menjalankan tugas jabatannya, sehingga pemeriksaan, pengawasan, penjagaan protokol notaris serta pemberian sanksi terhadap seorang notaris dilakukan oleh pihak Pengadilan berdasarkan regulasinya.

Pengadilan Negeri selanjutnya berwenang, apabila terbukti seorang notaris melakukan pelanggaran kode etik profesi dan/atau pelanggaran hukum, serta menurut pendapat pengadilan negeri salah satu hukuman yang dijabarkan di dalam pasal-pasal tersebut masih kurang dibandingkan dengan sifat tindakan-tindakan pelanggarannya, maka agar mengajukan usul kepada

${ }^{5}$ Tan Thong Kie, Studi Notariat \& Serba-Serbi Praktek Notaris, (Jakarta: PT Ichtiar Baru Van Hoevo, (selanjutnya disebut Tan Thong Kie I) hal. 545.

${ }^{6}$ Habib Adjie, Op.Cit., hal 169-170 
Menteri Kehakiman sehingga seorang notaris dapat dipecat dari jabatannya.Akan tetapi, pemberian peringatan, pemberhentian sementara dan usul pemecatan kepada Menteri Kehakiman tidak boleh dilaksanakan sebelum notaris yang bersangkutan didengar atau dipanggil secara wajar. Berlaku pula sebelum seorang notaris diberhentikan, maka proses pengadilan di Mahkamah Agung harus digelar terlebih dahulu. Dalam hal seorang notaris diberhentikan sementara, maka Pengadilan Negeri dalam waktu yang sama mengangkat seorang notaris pengganti.

Notaris yang dikenakan tuntutan perkara dan oleh pengadilan dinyatakan tanpa ada perintah untuk ditahan atau tetap ditahan atau dibebaskan kembali sesudah ada tuntutan perkara Pengadilan atau terjadi suatu proses perkara berdasarkan pasal 177 alenia 1 dari reglement op de strafourdering, yang di dalam wilayahnya notaris itu bertempat kedudukan, dapat diberhentikan sementara dari jabatannya sampai perkara itu diputus dan tidak dapat diubah lagi, sehingga notaris yang bersangkutan tidak dapat menjalankan tugas jabatannya dalam pembuatan akta apapun.

Keuntungan pemeriksaan protokol notaris pada sistem yang lama yaitu pemeriksaan yang dilakukan oleh pihak Pengadilan dalam pemeriksaan akta notaris apabila ada hal-hal yang diluar teknis atau mungkin di dalam teknis pembuatan akta itu menyimpang, maka pihak pengadilan dapat langsung memberi teguran kepada notaris yang bersangkutan untuk memperbaiki akta tersebut. Dimana apabila notaris tersebut tidak melakukan perbaikan terhadap akta yang dibuatnya maka akan menimbulkan permasalahan hukum yang melibatkan notaris dan dapat dijadikan tersangka setelah dipanggil dan diperiksa sebagai saksi.

Pengawasan terkait akta mulai mengalami peningkatan sejak berlakunya Undang-Undang Nomor 30 Tahun 2004 Jo Undang-Undang Nomor 2 Tahun 2014 Tentang Jabatan Notaris pada BAB IX Pengawasan diatur dalam Pasal 67 sampai Pasal 81. Adapun pengawasan dilaksanakan oleh Menteri dan dalam pelaksanaan pengawasannya menteri membentuk majelis pengawas. Majelis Pengawas Notaris merupakan kepanjangan tangan dari Kementerian Hukum dan Hak Asasi Manusia. Pasal 67 UUJN mengatakan bahwa dalam mengawasi Notaris merupakan tugas Menteri, akan tetapi pada pelaksanaan tugasnya tersebut Menteri mendirikan Majelis Pengawas. Pengalihan wewenang tersebut dapat dikatakan sebagai delegasi.Majelis pengawas yang dimaksud adalah Majelis Pengawas Daerah masing-masing di wilayah kerja dan kedudukan notaris.

Kewenangan pengadilan untuk mengeluarkan salinan akta dari protokol notaris yang minuta aktanya sudah berumur 25 tahun tetapi tidak diserahkan kepada MPD merupakan hal yang bertentangan dengan regulasi yang baru.Peraturan jabatan notaris telah mengatur dari Pasal 50 sampai 
dengan Pasal 54 yang berwenang mengeluarkan salinan akta dari protokol notaris yang telah berusia 25 tahun adalah kewenangan Pengadilan. Namun setelah berlakunya Pasal 63 Undang-Undang Nomor 2 Tahun 2014 untuk mengeluarkan salinan akta dari protokol notaris yang minuta aktanya sudah berumur 25 Tahun menjadi kewenangan MPD dan harus segera diserahkan kepada mereka agar lebih terfokus dalam pengawasan dan penjagaannya.

\section{Perlindungan Hukum Terhadap Notaris dan Para Pihak/Ahli Warisnya}

Menurut hukum di Indonesia, tidak ada pekerjaan atau profesi yang pertanggungjawabannya tidak dibatasi. Pekerjaan, profesi serta jabatan apapun yang diemban seseorang seperti salah satunya sebagai pelaksana dari pemerintahan entah termasuk dalam struktur negara atau organisasi besar tertentu, pasti memiliki batasannya masing-masing ketika tugas jabatan dijalankan. Pertanggungjawaban tersebut akan melekat selama pihak yang terkait masih aktif dalam jabatannya, sehingga ketika seorang pekerja/pejabat telah berakhir masa kerja jabatannya maka berakhir pula tanggungjawabnya. ${ }^{7}$ Karena hal tersebut, untuk tetap menjaga keteraturan kehidupan di masyarakat, maka pihak-pihak yang memiliki wewenang membuat regulasi untuk mengaturnya dan dapat dijadikan sebagai pedoman.

Regulasi yang ada kemudian menjadi suatu hukum yang mengikat bagi masyarakat, karena pada hakikatnya suatu hukum dibuat dengan memiliki tujuan memaksa dan membebankan tanggung jawab terhadap setiap perilaku yang dilakukan masyarakat. Hukum sebagai regulasi membatasi dan memiliki poin-poin tanggung jawab sebagai dasar perlindungan hukum. Adanya perlindungan hukum tersebut sebagai bukti pelayanan dari negara demi memberikan rasa aman sekaligus efek jera kepada masyarakat.

Perlindungan hukum yang berlaku dan dijalankan di Indonesia mengacu pada jaminan hak asasi manusia yang mengutamakan prinsip "wetmatigheid" yang artinya dasar dari tindakan pemerintah adalah UndangUndang yang memiliki tujuan supaya terwujudnya perlindungan hukum, maka regulasi yang ada dijadikan sebagai dasar utama sebagai perlindungan.Hal ini berlaku untuk setiap warga negara Indonesia sebagai individu maupun sedang menyandang profesi atau jabatan tertentu. Dasar hukum yang ada sebagai pedoman bagi mereka agar mengerti dan dapat terhindar dari permasalahan hukum apapun.

${ }^{7}$ Syaifurrachman, Aspek Pertanggungjawaban Notaris dalam Pembuatam Akta, (Bandung: Mandar Maju, 2011), hal. 34. 
Begitu pun dengan seorang pejabat notaris, dasar hukum dan juga pedoman dari jabatan seorang notaris untuk segala perbuatannya melaksanakan tugas jabatan didasarkan pada UUJN merupakan perwujudan perlindungan hukum preventif (pencegahan) yang diberikan sepenuhnya kepada seorang notaris, yang memiliki arti bahwa perlindungan hukum tersebut diberikan pemerintah sebelum terjadinya pelanggaran.Hal-hal yang ada pada peraturan perundang-undangan bertujuan untuk mencegah suatu pelanggaran dengan adanya indikator sebagai batasan saat menjalankan kewenangan dan mengatur hak dan kewajiban yang terkait dengan subjeknya.Sehingga seorang pejabat notaris diharapkan dapat terus menjunjung tinggi peraturan jabatan notaris, kode etika profesi notaris dan peraturan perundang-undangan lainnya.

Seorang notaris dalam menjalankan tugas jabatannya dituntut agar memberikan pelayanan terhadap masyarakat semaksimal mungkin.Siap bertanggungjawab mulai dari diangkat menjadi seorang pejabat notaris hingga berakhirnya masa kerja.Tidak diperkenankan untuk memihak dalam memberikan nasihat hukum kepada salah satu para pihak, menjaga diri sendiri agar selalu siap memberikan pelayanan dan meminimalisir permasalahan hukum yang dapat melibatkannya. Dengan begitu akan semakin menimbulkan tingkat kepercayaan masyarakat terhadap pejabat hukum bahwa dapat memberikan pelayanan sebagai bentuk kewajiban notaris dengan baik dan benar.

Berdasarkan hal tersebut, di sinilah fungsi peraturan jabatan notaris bagi pengemban jabatan notaris yang memiliki peran dan standar agar notaris bertindak secara professional dalam menjalankan tugas jabatannya, juga diharapkan dapat melayani masyarakat dengan sebaik-baiknya, sehingga perlu adanya batasan-batasan yang diterapkan agar notaris tetap maksimal dalam melayani. Seperti halnya usia biologis, yakni hanya sampai pada usia 65 tahun.

Bagi seorang notaris pengganti, tugas pokok dan fungsinya sama saja dengan notaris sebelumnya ditambah keterangan jika ia bertindak sebagai notaris pengganti. Namun, jika selama ia bertindak sebagai notaris pengganti dan tidak membuat akta, maka notaris pengganti tidak perlu bertanggungjawab apapun, begitu juga dengan pejabat sementara notaris. Berbeda halnya dengan pemegang protokol notaris atau notaris itu sendiri, jika protokol notaris yang dialihkan kepada notaris pemegang protokol, bukan berarti tanggung jawabnya beralih kepada notaris pemegang protokol yang baru. Hal tersebut menjadi wewenang MPN yang memberi ketentuan tempat penyimpanan protokol notaris yang pada saat peralihan protokol notaris akta sudah berumur 25 tahun atau lebih. 
Oleh karena itu, kewajiban yang dilakukan oleh seorang notaris tentunya tidak berlaku selamanya. Seorang pejabat notaris juga memiliki batasan mengenai jangka waktu pertanggungjawabannya pada akta yang telah dibuat. Dibatasi hal-hal seperti kesanggupan fisik dan rohani notaris ketika melaksanakan tugas jabatannya. Notaris yang telah berakhir masa kerjanya, pada dasarnya tidak memiliki kewenangan yang sama lagi dalam membuat -akta serta kewenangan lainnya seperti yang dimiliki oleh notaris yang masih menjabat. Namun, penjelasan Pasal 65 UUJN yang hanya ditulis dengan cukup jelas, terdapat kekaburan norma mengenai batasan jangka waktu pertanggungjawaban notaris yang tidak menjabat lagi. Pasal tersebut tidak menyebutkan dengan spesifik tentang jangka waktu kapan berakhirnya pertanggungjawaban notaris terhadap akta yang dibuatnya.

Hal tersebut dikarenakan kekuatan pembuktian akta yang telah dibuat oleh seorang notaris tidak hanya dapat digunakan pada saat notaris semasa hidup, setelah ia wafat pun akta yang ada tetap dapat memberikan bukti terhadap kejadian yang telah tertuang di dalam akta. Eksistensi akta dapat lebih lama dari pada pejabat yang membuatnya. Sehingga tanggung jawab mengenai simpan menyimpan protokol notaris oleh notaris pemegang protokol adalah salah satu cara agar keberadaan akta notaris dapat terjamin aman di bawah pengawasan MPD. Dalam hal ini terkhusus untuk minuta akta yang tidak diperkenankan keluar dari kantor notaris, begitu pun dengan protokol notaris yang telah dialihkan kepada notaris lain, tidak menggugurkan tanggung jawab notaris sebelumnya mengenai protokol tersebut meskipun telah pensiun.

Peraturan jabatan notaris mengatur bahwa seorang notaris memiliki wewenang untuk membuat suatu akta autentik. Kumpulan akta autentik yang berada pada protokol notaris tersebut merupakan hasil dari kesesuaian wewenangnya serta keterangan kehendak dari para pihak di dalam akta.Untuk permasalahan dengan notaris jika salah satu dari para pihak merasakan adanya kerugian yang berhubungan dengan akta yang telah dibuat, maka salah satu atau semua pihak yang dirugikan dapat mengajukan ke Pengadilan Negeri. Sehingga jika dikemudian hari, seorang notaris telah berakhir masa kerjanya sesuai dengan salah satu alasan yang terdapat di dalam UUJN, jika ia masih hidup maka ia akan tetap dipanggil dan diperiksa bersama dengan para pihak untuk memberikan kesaksian terkait substansi di dalam minuta akta. Namun, jika notaris terkait sudah wafat, maka akta yang dibuat dan para pihak memberikan kesaksian mengenai perbuatan hukum yang tertuang di dalam akta.

Jika ditelaah secara logika, pada hakikatnya cukup sulit diterima jika seorang notaris menjadi tergugat terkait akta yang dibuat olehnya. Padahal ruang lingkup kerja notaris adalah membuat akta berdasarkan hasil 
kehendak dari para pihak yang memiliki kepentingan dalam hal perbuatan dan/atau hubungan hukum tertentu. Seorang notaris juga tidak hanya mendengarkan kehendak dari para pihaksaja, mereka juga wajib untuk memberi nasihat-nasihat hukum yang sesuai dengan permasalahan aktanya. Jadi segala hal yang tertuang didalam akta sepenuhnya berisi keterangan dan kehendak para pihak yang berurusan. Sehingga pada Pasal 66 UUJN diatur mengenai perlindungan hukum yang dapat diberikan terhadap notaris yang tengah menjalankan jabatannya untuk ditetapkan menjadi saksi, tersangka atau terdakwa.

Pasal tersebut mengatur tentang prosedur permohonan izin kepada MPN terkait adanya kepentingan proses di peradilan yang mana jika Penyidik, Penuntut Umum serta Hakim yang membutuhkansalinan minuta akta dan/atau surat-surat yang melekat pada minuta akta dan/atau protokol notaris yang mana ada di bawah wewenang dan penyimpanan notaris, terlebih dahulu harus mendapat persetujuan dari MPN. Namun, ketentuan di dalam Pasal 66 UUJN tersebut terdapat titik kelemahan terhadap notaris yang sudah berhenti masa jabatannya karena perlindungan hukum pada pasal tersebut menjadi tidak berlaku, padahal notaris yang bersangkutan tetap dibebani tanggung jawab terhadap akta yang telah dibuatnya. Dengan kata lain bahwa notaris yang telah pensiun tidak mendapat keadilan distributif, yakni keadilan terkait dengan persamaan hak sebagai perlindungan hukumnya ketika akta terkait ternyata terdapat masalah.

Permasalahan akta yang menjadi faktor kemungkinan terjadinya kesalahan yang dilakukan oleh notaris dikategorikan dalam 2 faktor kesalahan, yaitu : faktor kesalahan pribadi dan faktor kesalahan dalam pelaksanaan jabatannya. Faktor kesalahan pribadi, prosedur yang harus dijalani memiliki persamaan dengan masyarakat pada umumnya yang mana dapat dituntut pertanggungjawabannya juga berlaku perlindungan hukum yang sama. Sedangkan faktor kesalahan dalam pelaksanaan tugas jabatan notaris, diperlukan prosedur tuntutan dan perlindungan hukum yang khusus dan berbeda dari masyarakat pada umumnya meskipun masa jabatan notaris tersebut telah berakhir.

Berdasarkan kekhususan tersebut, maka diperlukan adanya suatu organisasi pelindung notaris yang dapat menjadi filter dari pihak-pihak luar meskipun pihak tersebut memiliki wewenang dalam pelaksanaan jabatannya yang akan mengarah pada adanya kemungkinan penyitaan salinan minuta akta. Organisasi yang penulis maksud adalah Ikatan Notaris Indonesia (INI). INI diharapkan dapat menjadi pelindung dari permasalahan hukum pihak-pihak yang diduga tidak berhubungan bagi notaris yang bersangkutan. Untuk keperluan tersebutlah maka menjadi 
penting diaturnya perlindungan hukum bagi notaris sehingga keluhuran harkat dan martabat jabatannya dapat selalu terjaga, begitupun saat proses pemberian kesaksian dan menjalani proses hukum lainnya dalam pemeriksaan dan persidangan, dapat menjaga segala hal yang telah diketahuinya seperti keterangan isi akta yang merupakan kepentingan para pihak yang terkait di dalam akta tersebut serta menjaga minuta akta atau surat-surat yang dilekatkan pada minuta akta serta protokol notaris dalam penyimpanannya.

INI sebagai organisasi yang menaungi para pejabat notaris diharapkan dapat lebih menjamin jika dikemudian hari terjadi tindakan pemanggilan, pemeriksaan dan/atau penahanan terhadap notaris, yang mana hal-hal tersebut harus dilakukan setelah mengajukan izin kepada organisasi profesi dan telah dilakukan proses pemeriksaan sesuai dengan peraturan perundang-undangan yang berlaku agar terwujudnya kepastian hukum bagi seorang notaris yang merupakan pejabat umum.

Adapun ketentuan perlindungan hukum dalam UUJN dapat penulis uraikan sebagai berikut: mengenai Hak Ingkar Notaris, beberapa peraturan perundang-undangan telah memberikan hak ingkar atau hak untuk dibebaskan menjadi saksi berdasarkan beberapa hal yakni, hubungan keluarga yang sangat dekat, bahaya dikenakan hukuman pidana, statuskedudukan, pekerjaan dan rahasia jabatan.

Hak ingkar merupakan dampak dari kewajiban seorang notaris untuk merahasiakan segala hal yang diketahuinya. Adapun 15 dasar filosofi hak ingkar bagi beberapa jabatan bahwa letak kepercayaan berada pada masyarakat yang memiliki kepentingan, sehingga ketika seseorang berada dalam kesulitan dapat menghubungi pihak yang berwenang di bidangnya dan dapat dipercayaagar memperoleh bantuan yang sesuai dengan kebutuhannya pada bidang yuridis, medis atau kerohanian dengan keyakinan bahwa ia akan mendapat nasihat hukum, tanpa merasa dirugikan.

Kewajiban ingkar dan hak ingkar Notaristermaktub dalam Pasal 4 ayat (2), Pasal 16 ayat (1) huruf F dan Pasal 54 UUJN. Lebih lanjut Habib Adjie menyebutkan, bahwa hak Ingkar sebagai kewajiban ingkar Notaris" yang merupakan salah satu bagian dari sumpah/janji Notaris bahwa Notaris akan merahasiakan isi akta dan keterangan yang diperoleh dalam pelaksanaan jabatan Notaris sesuai dengan Pasal 4 ayat (2) dan Pasal 16 ayat (1) huruf F UUJN. ${ }^{8}$

Notaris dalam membuat akta berhak melakukan pelekatan sidik jari pada Minuta akta sesuai dengan Pasal 16 ayat (1) huruf c UUJN yang

${ }^{8}$ Ibid, hal. 35 
menyatakan dalam menjalankan jabatannya, notaris wajib melekatkan surat dan dokumen serta sidik jari penghadap pada minuta akta, sehingga adalah wewenang MPN mengawasi hal-hal yang terkait pemeriksaan kelengkapan dokumen pendukung dibuatnya minuta akta dikarenakan fungsi dan tujuanpelekatan sidik jari agar memperkuat alat bukti. Di sisi lain, pelekatan sidik jari tersebut diharapkan dapat lebih memberikan perlindungan hukum bagi notaris.

Adapun hal-hal yang berkaitan dengan prosedur pemanggilan notaris oleh penyidik, Penuntut umum atau hakim berdasarkan ketentuan Pasal 66 ayat (1) UUJN menyatakan bahwa, hal-hal yang berkaitan dengan kepentingan proses peradilan, penyidikan, penutut umum atau hakim dapat dilakukan dengan persetujuan MPN. Dalam hal ini pasal tersebut dengan jelas mengatur mengenaipihak yang berwenang mengeluarkan persetujuan berkaitanpemanggilan dan/atau pengambilan minuta akta dan/atau surat-surat yang melekat pada minuta akta atau protokol notaris.

Berdasarkan regulasi tersebut, makasaat ingin memberikan persetujuan, MPN terlebih dahulu harus melakukan proses pemeriksaan terhadap notaris yang diduga melakukan pelanggaran. Pemeriksaan dimaksud dilakukan sesuai dengan ketentuan Pasal 70 huruf a UUJN yang menyatakan, bahwa sidang diselenggarakan terlebih dahulu guna pemeriksaan terkait ada atau tidaknya dugaan pelanggaran pelaksanaan jabatan notaris. Setelah pemeriksaan diselenggarakan, hasil akhir dari pemeriksaan MPN berupa pemberian persetujuan atau penolakan permohonan penyidik, penuntut umum atau hakim, dituangkan dalam bentuk Surat Keputusan (SK).

Perlindungan hukum yang diberikan terhadap notaris terdapat 2 (dua) macam, yakni perlindungan hukum preventif dan hukum represif. Perlindungan hukum preventif berupa pelekatan sidik jari para pihak yang menghadap pada minuta akta. Sedangkan perlindungan hukum represif berupa hak ingkar yang dibereikan oleh undang-undang dan adanya persetujuan MKN pada saat notaris menjalani proses hukum penyidikan, penuntutan maupun persidangan di pengadilan. Sementara itu, perlindungan hukum bagi para pihak/ahli waris yang membutuhkan salinan akta dari protokol yang tersimpan di pengadilan negeridan telah berusia 25 tahun masih terdapat kekosongan hukum karena belum adanya regulasi yang mengatur lebih lanjut tentang hal tersebut dan belum dapat memberikan kepastian hukum terhadap para pihak di dalam minuta akta serta ahli warisnya. 


\section{KESIMPULAN}

Pengadilan Negeri sudah tidak mempunyai kewenangan untuk mengeluarkan salinan akta notaris yang telah disimpan dan berusia 25 tahun karena adanya Pasal 63 UUJN bahwa protokol notaris yang sudah berusia 25 tahun harus dialihkan kepada MPD. Perlindungan hukum bagi notaris yang bersangkutan, minuta akta yang protokolnya tersimpan di Pengadilan Negeri dan berusia 25 tahun adalah melekatnya hak ingkar dalam dirinya yang menyebutkan harus menjaga rahasia semua keterangan dari para penghadap yang membuat akta di hadapannya. Sedangkan perlindungan hukum bagi para pihak/ahli waris yang menbutuhkan salinan akta dari protokol yang tersimpan di Pengadilan Negeri dan telah berusia 25 tahun belum tercapai karena belum adanya aturan yang mengatur terkait hal tersebut sebagai bentuk dari kepastian hukum yang diinginkan oleh para pihak/ ahli warisnya.

\section{DAFTAR PUSTAKA}

\section{Buku}

Abdul Ghofur Anshori, 2009, Lembaga Kenotariatan Indonesia, Perespektif Hukum Dan Etika, Yogyakarta: UII Press.

Habib Adjie, 2008, Sanksi Perdata dan Administratif Terhadap Notaris Sebagai Pejahat Publik, Bandung: Refika Aditama.

Herlien Budiono, 2015, Kumpulan Tulisan Hukum Perdata Di Bidang Kenotariatan. Jakarta: Citra Aditya Bakti. , 2003, Akte Notaris Melaui Media Elektronik, Bandung: Upgrading -Refreshing Course Ikatan Notaris Indonesia.

Syaifurrachman, 2011, Aspek Pertanggungjawaban Notaris dalam Pembuatam Akta, Bandung: Mandar Maju.

Tan Thong Kie, Studi Notariat \& Serba-Serbi Praktek Notaris, Jakarta: PT Ichtiar Baru Van Hoevo.

\section{Peraturan Perundang-undangan}

Undang-Undang Nomor 30 Tahun 2004 tentang Jabatan Notaris Undang-Undang Nomor 2 Tahun 2014 Tentang Jabatan Notaris tentang Perubahan atas Jabatan Notaris 